\title{
EMPLOYMENT OF NOT STANDARDIZED CONTAINERS BY RST AND THEIR INTERFERENCE IN THE PHYSIOLOGICAL QUALITY OF SEEDS OF Pinus elliottii
}

\author{
Dane Block Araldi ${ }^{1}$, Jerson C. Guedes ${ }^{1}$, Clérison Perini ${ }^{1}$, Francine Lautenschlager ${ }^{2}$, Ivan Ricardo Carvalho ${ }^{3}$, \\ Deivid Araújo Magano ${ }^{3}$
}

\begin{abstract}
The determining factor for ensuring success in a forest enterprise is causally linked to the quality of the seeds used in the nursery. In this sense, the objective of this study was to evaluate the physiological quality of Pinnus Elliottii in different containers compared to the standardized test by RST. Cellboxes (tissue culture boxes), with different diameters and cell numbers, respectively $(0.7,1.1,16$ and 21 $\mathrm{mm}$ and $96,48,24,12$ ) with circular blotting paper substrates were used. The experimental design used was a completely randomized with 5 treatments and 8 repetitions. The treatment (T1) with 96 cells showed the highest average germination and the lowest fungal infestation, compared to the gerbox container. Cellbox containers showed better values for germination, showing that the division of cells positively influences the health quality of Pinus elliottii Engelm var. elliottii.
\end{abstract}

Keywords: cellbox, crop protection, forest, fungi, quality.

\section{INTRODUCTION}

Brazil is considered a forest country with approximately 463 million hectares covered by native and planted forests, which make up $54.4 \%$ of its national territory. According to the National Forest Information System (SNIF, 2014), around seven million hectares are occupied by planted forests, basically composed of eucalyptus, pine, acacia, rubber, paricá, teak, araucaria, populus and other species acclimated to more diverse environmental conditions.

Despite the supremacy of Eucalipthus spp., which covers $71 \%$ of the Brazilian landscape of planted forests, in the southern region of the country, the species Pinus elliottii Engelm var. elliottii (Pinaceae) is the forest species most used in reforestation due to its versatility of uses, ranging from landscaping to the extraction of turpentine for the preparation of paints and insecticides.

The forest species segment has been organizing itself effectively with its own legislation to meet the demand for seeds of good sanitary and physiological quality (Vechiato, 2010). In Brazil, the current Rules for Seed Testing are based on the International Rules of ISTA (International Seed Testing Association, 1993, 1999) and
AOSA (Association of Official Seed Analysis, 1983), which regulate the methods to be used in the analysis of seeds in international trade (Piña-Rodriques, (2004). However, the possibility of spreading seed diseases and pests is a constant threat and has already been widely addressed by experts (Bettiol \& Morande, 2009).

The inclusion of health standards in forest seeds, aiming to control the quality of seeds and seedlings produced, is strategic to hinder the introduction and dissemination of pathogens (Vechiato, 2010). Regardless of the medium in which the seed is placed to germinate, it must always remain moist so that there is no interference in the development of the seedling (Piña-Rodrigues et al., 2004). This humidification should be as uniform as possible in germination for the control of pathogenic microorganisms and that, consequently, provides a better development of seedlings. The knowledge of germination is of fundamental importance to define protocols and strategies that favor the development of seeds with quality, in less time and under different seed sizes and under different containers.

After physiological maturity, the seeds undergo a continuous and irreversible process of deterioration or aging. Understanding this process has become increasingly important because it is through it that research has

\footnotetext{
${ }^{1}$ Universidade Federal de Santa Maria - UFSM, Santa Maria - RS

${ }^{2}$ Universidade Estadual do Centro Oeste do Paraná - Unicentro, Guarapuava-PR

${ }^{3}$ Universidade Regional do Noroeste do Estado do Rio Grande do Sul - Unijuí-Ijuí -RS.
} 
developed methods to determine the physiological potential or vigor of seed lots (Custódio, 2005). Considering that the standard germination test has limitations, not revealing subtle differences in performance between batches, as well as the delay in obtaining the results, there is an increasing need for the improvement of tests aimed at evaluating seed germination, mainly, with regard to obtaining consistent information and, preferably, in relatively short periods (Torres, 2005). For a more accurate analysis of seed quality, it is necessary to complement, according to Araújo et al. (2011), the information provided by the germination test with vigor tests, thus making it possible to select the best lots for commercialization and sowing.

In this context, the containers are considered one of the important factors to be evaluated in the germination process in the physiological quality of the seeds. The choice of the container must be judicious, as it influences germination and it is necessary to be free of phytopathogens and undesirable seeds, however with the different types of seeds it is sometimes difficult to find a container with all the characteristics that need the germination of the seeds, hence the research needs to obtain a container close to the ideal (Araújo Neto et al., 2009).

In view of these considerations, the optimization of the germination process under the conditions of the different types of containers, the present work aimed to evaluate the physiological quality of Pinus elliottii seeds in different containers compared to the gerbox container standardized by RST.

\section{MATERIAL AND METHODS}

\subsection{Characterization of the study site}

The study was carried out in the municipality of Santa Maria-RS, located in the southern half of the state in a region surrounded by hills, from the end of the basaltic spill occurred in the Pleistocene, in the geographical position $29^{\circ}$ $41^{\prime} 02^{\prime \prime} \mathrm{S}$ " $53^{\circ} 48$ '25 "W, average altitude of $113 \mathrm{~m}$ above sea level, average annual temperature $19.5^{\circ} \mathrm{C}$, humid subtropical climate, average rainfall of $1800 \mathrm{~mm}$, according to the Köppen classification used as "Cfa" (MORENO, 1961). The analyzes were carried out at the Entomology, Phytopathology and Silviculture Laboratories at CCR / UFSM Santa Maria, RS.

\subsection{Seeds obtaining}

The seeds of Pinus elliottii Engelm var. elliottii (Pinaceae) used in the research come from FEPAGRO/
Floresta (State Foundation for Agricultural Research/Forest - Santa Maria/RS) (Figure 1), collected from matrix trees belonging to lot $\mathrm{n}^{\circ} 57 / 201$.

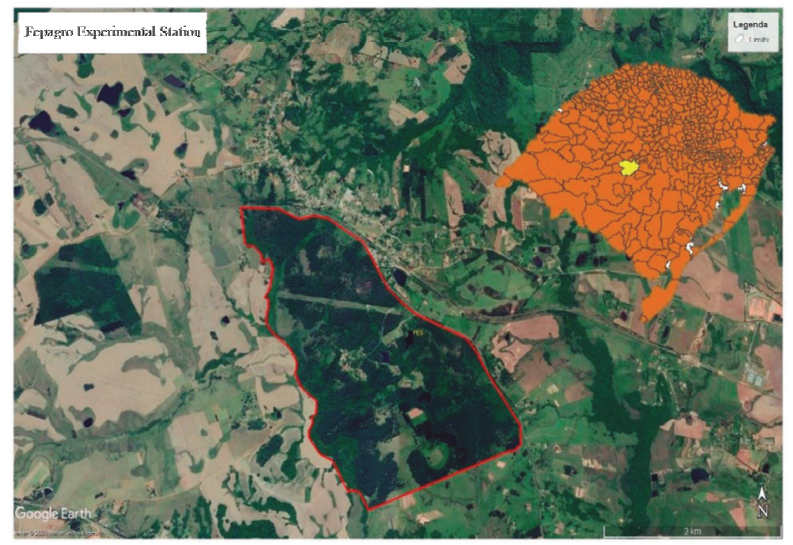

Figure 1 - Localization of Santa Maria in the Rio Grande do Sul State and Fepagro Experimental Station, RS, Brazil.

\subsection{Description of types of containers}

The containers used for germination are tissue culture boxes with flat-bottomed cells, serrated edges and sealing ring caps to reduce evaporation (condensation), risks of cross contamination and handling errors, cells identified with an alphanumeric code for easy identification, molded in high transparency polystyrene free of DNase (Deoxyribonucleases), RNase (Ribonucleases), pyrogens and toxins.

For the study of germination and germination speed index, four containers with dimensions of $12.5 \times 8.5 \times 2.0 \mathrm{~cm}$ ) were used, with four different diameters $0.7 ; 1.1 ; 1.7$ and $2.1 \mathrm{~cm}$ and $96,48,24$ and 12 number of cells respectively, called "cellbox", blotting paper substrate in the form of discs according to the diameter of each cell, controlled humidification with distilled water equivalent to 3.0 times the mass of the non-hydrated paper, in addition to the gerbox container, plastic box of polystyrene material, transparent crystal, $250 \mathrm{ml}$ capacity measuring $11 \mathrm{x} 11 \mathrm{x}$ $3.5 \mathrm{~cm}$ with 100 dents blotting substrate, 96 dents used, quantity according to cellbox containers. The characteristics of the containers, quantity, cell diameters in the four types of containers and the gerbox box in the five treatments can be seen in Figure 2. 


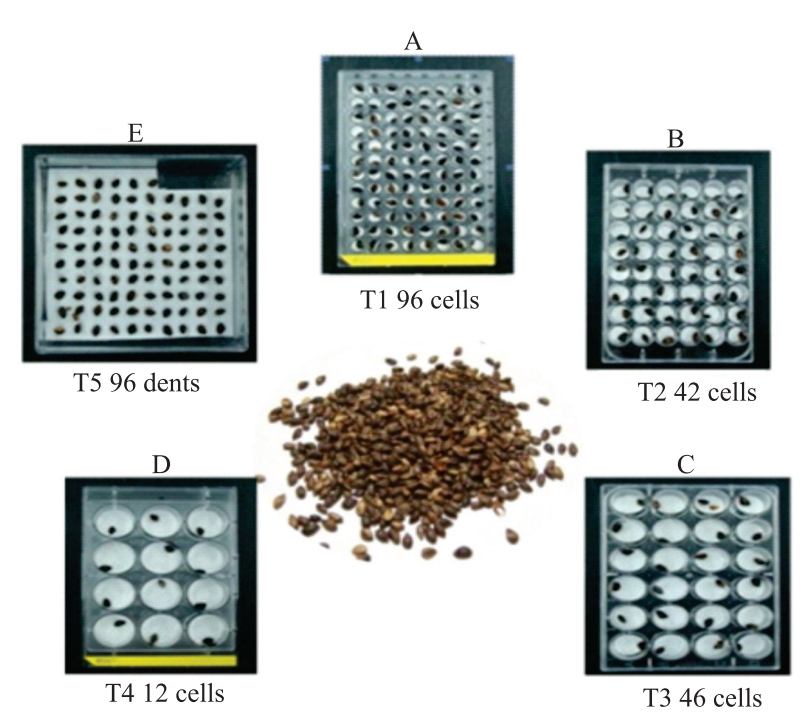

Figure 2 - Types of containers used in the five treatments: A (96 cells), B (42 cells), C (46 cells), D (12 cells) and $\mathrm{E}$ (96 seeds) in the gerbox.

\subsection{Germination test}

The containers with the seeds were placed in BOD chambers (Biochemical Oxigen Demand) with

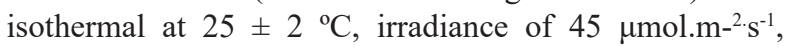
12-hour photophase and the seeds were humidified using a single-channel micropipette type Eppendorf Repeater Pipette 4780 with a capacity of $2.5 \mathrm{ml}$ with distilled water, with replacement of humidification whenever necessary.

The number of germinated seeds was monitored daily, observing the morphological changes over 11 days. The seeds were considered germinated when they showed protrusion of the primary root with growth from $2 \mathrm{~mm}$ in length.

The experiment was considered concluded, when germination was null in the eight replications and in the five treatments for two consecutive counts, which justified the variation in the number of days presented in the experiment.

\subsection{Experimental design and statistical analysis}

The experiment was carried out using a completely randomized design with five treatments, eight repetitions totaling 3840 seeds, 768 seeds in each treatment. Statistical analysis was performed by analyzing the variance and the means were compared using the Tukey test at 5\% probability, using the SAS program. For germination analysis, the method (Borghetti and Ferreira, 2004) was used, which represents the percentage of germinated seeds in relation to the number of seeds willing to germinate, under certain experimental conditions according to the equation:

$$
\mathrm{G} \%=\left(\Sigma_{\mathrm{nj}} \mathrm{N}^{-1}\right) * 100
$$

where $\Sigma_{\mathrm{nj}}$ is the total number of seeds germinated in relation to the number of seeds arranged for $(\mathrm{N})$, data that are expressed as a percentage.

\subsection{Germination speed index (GSI)}

Another index often used for germination measurements is the Germination Speed Index. According to the formula proposed by Maguire (1962), symbolized by GSI, the number of seedlings emerged was evaluated daily until the emergence stabilized. To evaluate the survival of seedlings, the total number of seedlings emerged and the total number of seedlings that remained alive for growth evaluations were computed, and the percentage relationship between the two was expressed as a percentage of survival in which the number of seeds or normal seedlings counted daily:

$$
\mathrm{IVG}=\mathrm{G}_{1} / \mathrm{N}_{1}+\mathrm{G}_{2} / \mathrm{N}_{2} \ldots \mathrm{G}_{\mathrm{n}} / \mathrm{N}_{\mathrm{n}}
$$

Where: $G_{n}$ is the number of diaspores, E1 E2 ... En is the number of normal seedlings in the first, second until the umpteenth observation $\mathrm{N}_{1} \mathrm{~N}_{2} \ldots \mathrm{N}_{\mathrm{n}}$ number of days (or hours) after sowing.

\section{RESULTS AND DISCUSSION}

In order to standardize the evaluations and obtain consistent results during the tests performed, it was found that the comparative factors of the gerbox and cellbox containers acted independently for the parameters studied and analyzed individually, both showing difference in the containers both in germination $(\mathrm{G} \%)$ as in the germination speed index (GSI). Analyzing the results obtained in this assay, it was observed that the treatment $\mathrm{x}$ container the interaction was significant $(\mathrm{F}=15,064$; d.f. $=39 ; \mathrm{p}<0,05)$ for Germination, according Table 1.

In the $\mathrm{T} 1$ treatment, the highest germination average was verified in the container factor with the largest number of cells (96) with the smallest diameter $(0.7 \mathrm{~mm})$ respectively when compared to the gerbox container (T5) standardized by the RST (Figure 2). This suggests that there was a better interaction of the seeds in relation to the diameter of the cells, increasing the area of contact with 
the seeds in the containers and a greater homogenization in the humidification, consequently, reducing the fungus infestation, due to the presence of a sealing ring in the cells of the containers. According to Piña-Rodrigues; Figliola (2004) recommends maintaining a wide spacing between seeds to avoid contamination of fungi or bacteria between them, an adequate spacing, that is, 1.5 to five times the size of the seeds. Therefore, the cellbox containers keep the seeds isolated, making it difficult to spread contaminating organisms. Considering that this container standardized by RST, does not provide better water absorption by the seeds in a homogeneous way. In germination chambers, it is possible to verify that often there is a saturation of water on one side of the containers in the humidification process, due to the shelves being out of level or even arched by excessive weight of the containers, negatively influencing and masking the germination results, increasing the possibility of disease infestation, while in cellbox containers under identical conditions, seeds are able to germinate faster and with greater uniformity providing better physiological quality.

Table 1 - Means for Germination Test using different containers

\begin{tabular}{ll}
\hline Treatments & Means $^{1}$ \\
\hline T1 96 cells & $90,66 \mathrm{a}$ \\
T2 42 cells & $85,39 \mathrm{a}$ \\
T3 46 cells & $73,46 \mathrm{~b}$ \\
T4 12 cells & $70,83 \mathrm{~b}$ \\
T5 Gerbox & $65,62 \mathrm{~b}$ \\
\hline
\end{tabular}

Similar behavior was obtained with comparative results of seeds of the species Schinus teribenthifolius Raddi (Anacardeacea) with tissue culture containers (cellbox) in different diameters and quantity of cells, comparing to the gerbox container standardized by the RST. It proved quite satisfactory to meet the objectives presenting better values for germination and Germination Speed Index (GSI) and a lower incidence of fungi when the containers with the largest number of cells and the smallest diameters (0.7 $\mathrm{mm}$ and 96 cells) (ARALDI et al., 2011). Araldi et al. (2011) found results that converge with similar work where it was obtained in a study carried out on extracts of secondary metabolites of the macromorphological characters of Hovenia dulcis Thunb. (Ramnaceae) in various concentrations, used in germination, germination speed index and seedling development of the native species of Parapitadenia rigida Benth. (Brenan) Fabaceae to verify the allelopathic effect of this species using tissue culture vessels (cellbox) with 12 cells and $12 \mathrm{~mm}$ in diameter and 24 cells with $21 \mathrm{~mm}$ in diameter, respectively, the results for the specific objectives of the work resulted regarding the containers. Thus, considering the study to obtain a response depending on the containers in physiological quality, it can be observed that the highest averages of the germination percentage were in the $\mathrm{T} 1$ and $\mathrm{T} 2$ treatments (containers with 96 cells with $0.7 \mathrm{~mm}$ in diameter and containers with 48 cells with $11 \mathrm{~mm}$ in diameter respectively) and the lowest average germination occurred in treatment T4, (containers with 12 cells with $21 \mathrm{~mm}$ in diameter). Analyzing the results of Germination Speed Index , for the interaction, there was not significant difference between treatments. In this sense, the results for GSI, could be seen in Figure 3.

When analyzing the stages of the GSI (Germination Speed Index) data process as a function of the interaction between the cells $\mathrm{x}$ gerbox container factors, it was observed that the highest average of the GSI (1.78) provided higher values in the treatment T2 containers with 48 cells and $11 \mathrm{~mm}$ in diameter totaling an GSI of 14.24 in relation to the others. On the other hand, the T4 treatment was where the lowest GSI mean occurred (1.20) in containers with 12 cells and $21 \mathrm{~mm}$ in diameter, also changing to the lowest GSI of 9.60.

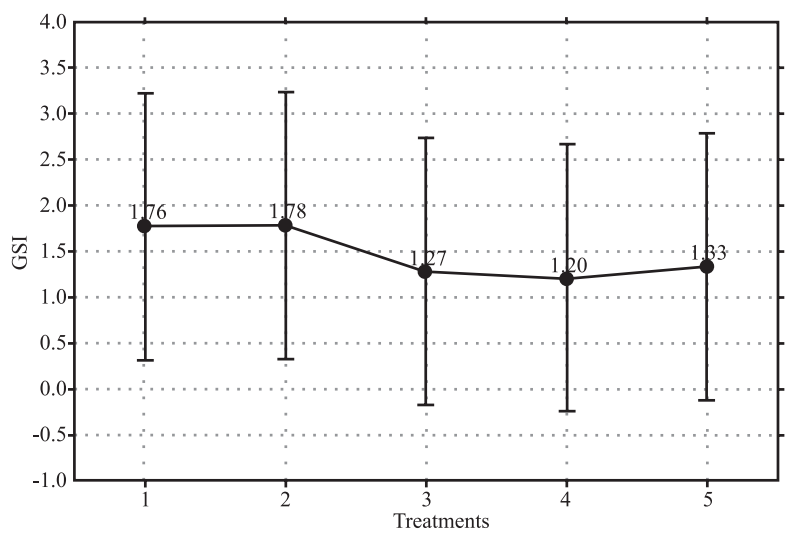

Figure 3 - Graph of the GSI means according to the treatments, with confidence intervals for the means $(0.95)$ in the vertical bars.

Another important factor is related to the larger diameter of the cells. Usually, when working with forest seeds, it is possible to observe the greater infestation of microorganisms due to the size of the seed using the traditional method, what not happens with the cell boxes. This way, due to the practicality of using cell box 
containers (tissue culture box), there is less contamination by microorganisms and the ease of seed evaluation, which can be indicated for carrying out seed germination tests.

\section{CONCLUSION}

Cell boxes showed potential for use in the germination test, promoting better results than the traditional methodology to Pinnus elliottii seeds, related to germination and less contamination by fungi increasing the physiological quality.

\section{ACKNOWLEDGMENTS}

The Coordination of Superior Level Staff Improvement (CAPES) for the scholarships granted and financial assistance.

\section{REFERENCES}

ARALDI, D. B. Interferência Alelopática de Extratos de Hovenia dulcis Thunb. na germinação e crescimento inicial de plântulas de Parapiptadenia rigida (Benth.) Brenan. (Doctoral thesis) - UFSM, CCR - PPGEF, 2011. 201p.

ARAlDi, D. A.; MAGistral, I. C.; COSTA, E. C.; SOUZA, D. B. Avaliação na germinação de sementes de Schinus terebenthifolius Raddi, em diferentes recipientes. Iv simpósio brasileiro de agropecuária sustentável. I congresso internacional de agropecuária sustentável. 01 a 03 de agosto de 2012. Universidade Federal do Rio Grande Do Sul. Porto Alegre-RS, p.925-928, 2012.

BIOMEX BIOTECNOLOGIA. Distribuidora de produtos científicos. Accessed on 04/29/2015. http://www. biomexbiotecnologia.com.br/produtos/categoria/1/page:3

BETTIOL, W.; MORANDI, M. A. B. Biocontrole de doenças de plantas; usos e perspectivas. Jaguariúna; Embrapa Meio Ambiente, 2009. 341p.

BRASIL. Ministério da Agricultura, Pecuária e Abastecimento. Regras para análise de sementes. Brasília: MAPA/ACS, 2009. 395p.

CARVAlHO, N. M.; NAKAGAWA, J. Sementes. Ciência, tecnologia e produção. Campinas, Fundação Cargill, 1983. $329 \mathrm{p}$.

CUSTÓDIO, C. C. Testes rápidos para avaliação do vigor de sementes: uma revisão. Colloquium Agrariae, v.1, n.1, p.29-41, 2005. DOI: 10.5747/ca.2005.v01.n1.a005
DAVIDE, A. C.; SILVA, E. A. A. Produção de sementes e mudas de espécies florestais. 1 ed. Lavras: Ed. UFLA, 2008. 175p.

FERREIRA, A. G.; BORGHETTI, F. Germinação do básico ao aplicado. Porto Alegre: Artmed, 2004. 322p.

ISTA. International Seed Testing Association. International rules for seed testing. Seed Science and technology, v.21, supl. 1-288, 1993.

LIMA JUNIOR, M. J. V. Manual de procedimentos para análise de sementes florestais ed. Manual de procedimentos para análise de sementes florestais. Manaus, Amazonas, Brasil: UFAM, 2010. 146p.

MAGUIRE, J. D. Speed of germination - aid in selection and evaliation for seedling emergence and vigor. Crop Science, v.1, p.176-177, 1962. http://dx.doi.org/10.2135/ cropsci1962.0011183X000200020033x

OLIVEIRA, E. C.; PIÑA-RODRIQUES, F. C. M.; FIGLIOLIA, M. B. Proposta para padronização da análise de sementes. Revista Brasileira de sementes, v.11, n.1,2,3. p.1-25. 1989.

PIÑA-RODRIGUES, F. C. M.; AGUIAR, I. B. Maturação $e$ dispersão de sementes. Brasília - DF: Associação Brasileira de Tecnologia de Sementes, Comitê Técnico de sementes florestais, v. 6, p. 215-74, 1993.

SALES JÚNIOR, R.; BELTRAN, R.; VICENT, A.; ARMENGOL, J.; GARCÍA-JIMÉNEZ, J.; MEDEIROS, E. V. Controle biológico de Monosporascus cannonballus com Chaetomium. Fitopatologia Brasileira, v.32, n.1, p.70-74, 2007. https://doi.org/10.1590/S0100-41582007000100011

SCREMIN-DIAS E. et al. Produção de mudas de espécies florestais nativas: manual. Campo Grande, MS: Ed. UFMS, 2006. 59p, il., 27 cm. (Rede de sementes do Pantanal; 2).

Sistema Nacional de Informações Florestais - SNIF. Accessed on 01/09/2015. http://www.florestal.gov.br/ snif/.

TORRES, S. B. Envelhecimento acelerado em sementes de pimenta-malagueta Capsicum frutescens L.). Revista Ciência Agronômica, v.36, n.1, p.98-104, 2005.

VANZOLIN, S.; MEORIN, E. B. K.; SILVA, R. A.; NAKAGAWA, L. Qualidade sanitária e germinação de sementes de pinhão-manso. Revista Brasileira de Sementes, v. 32, n. 4, p. 9-14, 2010. https://doi.org/10.1590/S010131222010000400001

VECHIATO, M. H. Importância da qualidade sanitária de sementes de florestais na produção de mudas. Centro de 
Pesquisa e Desenvolvimento de Sanidade Vegetal, n.136, 2010.

WAGNER JÚNIOR, A.; SANTOS, C. E. M.; SILVA, J. O. C.; ALEXANDRE, R.S.; NEGREIROS, J.R.S.; PIMENTEL, L.D.; ÁLVARES, V.S.; BRUCKNER, C.H.
Influência do $\mathrm{pH}$ da água de imbebição das sementes e do substrato na germinação e desenvolvimento inicial do Maracujazeiro doce. Revista Brasileira de Agrociência, v.12, n.2, p.231-236, 2006.

Recebido para publicação em 18/03/2019, aprovado em 08/07/2020 e publicado 30/07/2020. 